\section{SRC Members}

THE Secretary of State for Education and Science, Mrs Margaret Thatcher, has this week appointed two new members to the Science Research Council to replace Professor Sir Ronald Nyholm and Professor P. A. Sheppard, who have retired from the council. They are Professor H. Elliot of Imperial College, London University, and Professor R. Mason of the University of Sussex. The composition of the council from October 1 will then be: Professor Sir Brian Flowers (chairman), Dr A. H. Chilver, Dr D. S. Davies, Dr E. Eastwood, Professor H. Elliot, Professor H. Ford, Professor J. C. Gunn, Professor F. Hoyle, Professor H. L. Kronberg, Professor R. Mason, Professor P. T. Matthews, Dr J. W. Menter, Professor E. W. J. Mitchell, Mr D. L. Nicolson, Dr E. J. Richards and Professor M. M. Swann.

\section{NUCLEAR REACTORS}

\section{All Sef af Dounreay}

Although the construction of the British prototype fast breeder reactor is running about eighteen months behind schedule, it is still ahead of similar projects in other countries. The prototype is being built by the Nuclear Power Group at the United Kingdom Atomic Energy Authority Experimental Reactor Establishment at Dounreay in the North of Scotland, and should be completed at the end of this year.

The original plan was that the reactor system should deliver power to the

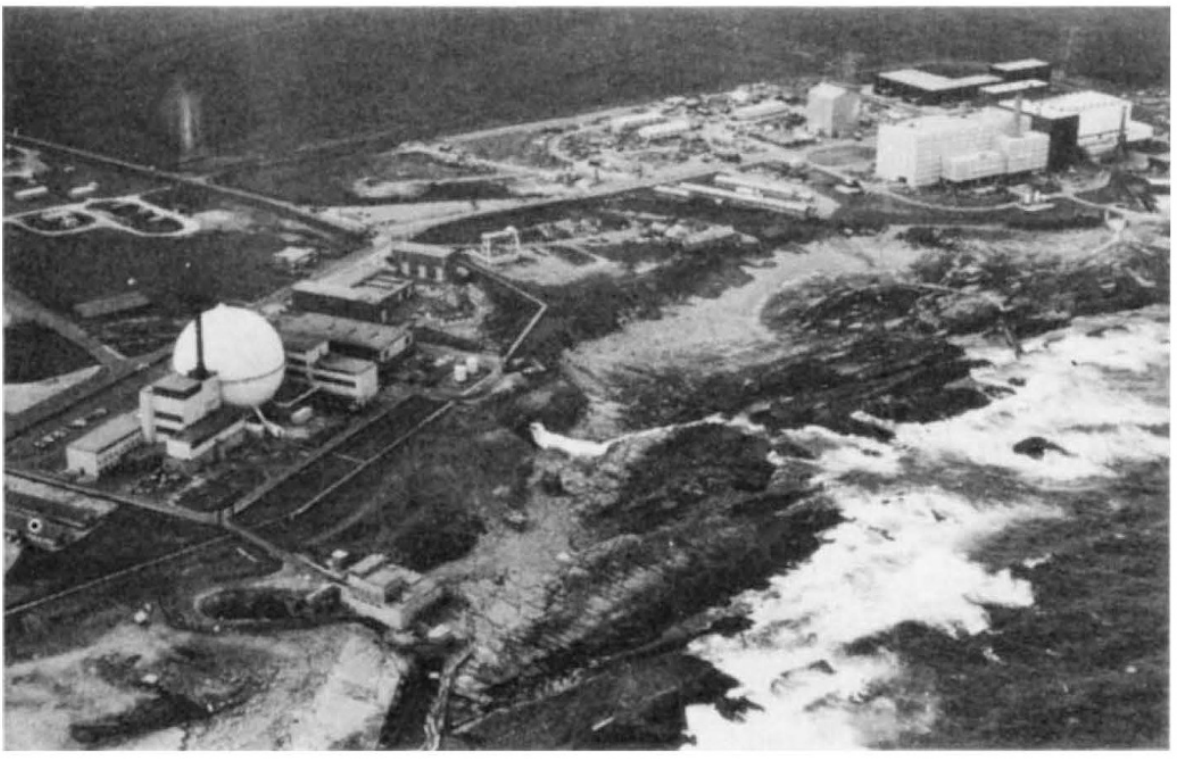

The Dounreay Experimental Reactor Establishment. The prototype fast reactor is in the right background, and the older Dounreay fast reactor is in the left foreground.
North of Scotland Hydroelectric Board during the first half of this year, but because of trouble with the construction of the roof of the reactor vessel, commissioning is now expected to take place early in 1972 with the first output of elecricity at the end of the year. By contrast with the smaller Dounreay fast reactor which first went critical twelve years ago and has been producing about 14 megawatts (MW) of electricity as well as providing a valuable irradiation facility, the prototype fast reactor (which has cost about $£ 38$ million) will generate at least $250 \mathrm{MW}$ and earn about $£ 4$ million a year from electricity sales. A further $£ 2$ million a year will probably accrue from rental of irradiation space in the core.

The Dounreay prototype fast reactor the small experimental fast breeder and the reactors needed for a new generation of nuclear power stations. The Central Electricity Generating Board is seriously considering the feasibility of fast breeder reactor stations and proved commercial systems could also be sold abroad provided that the designs are not so geared to the requirements of the Central Electricity Generating Board that they are unattractive to other potential customers (a situation that may account in part for the poor response to the British advanced gascooled reactors). Discussions between the Atomic Energy Authority and the Central Electricity Generating Board have led to a proposal that a 1,300 MW fast reactor power station should be started in 1974. This would cost about $£ 130$ million, but any decision to go ahead with such a project cannot be taken until the satisfactory operation of the Dounreay prototype fast reactor is assured and the thorny problem of represents an important link between siting fast reactors near centres of population is at least partially resolved. The Central Electricity Generating Board would certainly not be happy with a remote station because of the high costs of electricity transmission. A definite choice of site for the first commercial fast reactor will, however, have to be made during 1972 if the rather ambitious 1974 deadline is to be met.

In spite of the interruptions in the Dounreay prototype reactor programme, only the Russian 350 MW prototype reactor at Shevchenko is being built on a comparable timescale; a full-size Russian system is, however, unlikely to be a serious commercial competitor in the West. A French $250 \mathrm{MW}$ prototype reactor project is under way at Marcoule, but the core is not expected to go critical before 1973. In the United States General Electric and Westinghouse have designed a "demonstration" fast breeder reactor but construction has not yet started.

Britain is also involved in two collaborative fast reactor ventures in Europe. In 1969, the Nuclear Power Group joined representatives of eight European countries in a project to investigate gas cooled fast reactors (as opposed to the sodium cooled fast reactors such as the Dounreay prototype); the group is also involved with Kraftwerk Union (through its associated company Interatom), Belgonucleaire and Neratoom in an agreement to market fast reactors eventually on a worldwide basis. Interatom, Belgonucleaire and Neratoom are at present working on the design of a $300 \mathrm{MW}$ fast reactor to be built in West Germany.

\section{SPACE SCIENCE}

\section{Probing Mars}

from our Soviet Correspondent

The Soviet Mars-2 and Mars-3 probes, launched on May 19 and 28, 1971, and now half-way through their six-month voyage to their target, not only carry experiments for the study of Mars and circum-Martian space, they also have on board a number of experiments intended to operate during the voyage itself. These are intended to measure magnetic field strength, the flux of charged particles and study the solar wind.

The solar wind experiment, which appears to be the most important to the Soviet space programme at this stage, is designed to determine the velocity, temperature and composition of the principal components of the solar wind and the variation of these parameters with time and distance. It includes an ion-electron spectrometer unit, capable of measuring the spectral 